\title{
ON THE ISSUE OF INTENSIFICATION AND THE CHOICE OF INTENSIFIER
}

\author{
O. S. POLISHCHUK, PhD in Philology, Associate Professor, \\ National University of Life and Environmental Sciences of Ukraine \\ E-mail: oleksandr_polishchuk@ukr.net \\ ORCID: 0000-0001-9306-617X
}

\begin{abstract}
One of the main issues, which relates to the study of the category of intensity and draws much attention of linguists is the exact description of its position among other semantic categories, the definition of its boundaries, interconnection and interaction. The subject of this work is the semantic category of intensity, which is inherent, at least indirectly, in principle in any linguistic situation, and which can be embodied in the language in a variety of ways. The most interesting is the level of phraseology, because stable comparative phrases capture traditional national images and representations preserved from the earliest times, and allow demonstrating the specificity and relevance of the symbols of individual nations. The purpose of this study is, firstly, to analyse the essence and limits of the semantic category of intensity, its position and relationship with other linguistic categories; and secondly, to review of the means of expressing this category on the appropriate language levels; and, thirdly, on the background of the linguistic corps, to compare Russian and English stable comparative phrases.
\end{abstract}

Keywords. intensification, intensity, intensifier gradation, gradualism, sign, trait

Introduction. In any act of verbal communication, communicators pursue certain nonverbal goals that ultimately regulate the interlocutor's activities. Numerous linguistic studies show that the effectiveness of speech influence is achieved through the use of various expressive means of language, the level of argumentation, and the emphasis on the most significant elements of the utterance. After all, to enhance the impact of a statement on an interlocutor, the speaker consciously or non-consciously uses amplifying means of the language, where the term "amplification" as a synonym for the term "intensification" means the expression of a high degree of quality, intensity of an action or state or a system of multi-level means serving the expression of amplification.

There are a lot of papers that deal with particular aspects of the intensity category. The lexical means of expressing intensity in the sphere of verbal and adjective vocabulary, phraseological, syntactic and word-formation means of expressing intensity, including using indicators of verbal action methods, are analyzed. Nowadays scientists attempt to trace the interaction of intensity with other components of the lexical meaning of a word. There are also studies of the intensity on the material of dialect vocabulary.

The concept of "intensity" is not a new term in linguistic research. Even a simple list of publications in recent years shows how often such concepts as "intensity", "intensification", "intensives" or "intensity components" appear in works on linguistics.

Studying different ways of transmitting the same content in different languages serves not only practical purposes but also deepens knowledge about the relationship between language and thinking thus it has a considerable methodological and theoretical significance of comparative studies. The contrastive analysis of two languages is most effective for

(C) O. S. Polishchuk

«International journal of philology» | «Міжнародний філологічний часопис» Vol. 10, № 1, 2019 
comparison the integral systems of these languages.

However, according to V.N. Yartseva taking into account the stratification nature of the language system, its necessary to begin with a comparison of single-order phenomena in the compared languages, because of some similarity of the compared phenomena can we find out the degree of their similarity and contrasts [14, p. 3].

At the same time, scientists state out that in contrastive studies, the problem of equivalence and, in particular, the establishment of functional semantic equivalence acquires a special meaning $[1$, p. 5].

Analysis of recent research and publications. Describing the system of functional-semantic fields of the Russian language, A. V. Bondarko marks out a group of fields with a qualificativequantitative kernel, among which exist the fields of quality, quantitativeness and comparativity [3, p. 23]. There is no doubt that all these three fields in the language interact. Thus, the field of comparativity is represented by two microfields: the microfield of inequality and the microfield of equality of a qualitative sign (its quantitative characteristic) [6, p. 114]. Thus, the qualitative attribute of the subject is also quantified in terms of gradual or intensity. The gradual category of a qualitative attribute is recognized as one of the most universal semantic categories. Y. Y. Vorotnikov explains gradation as the ability of a qualitative sign to be the «norm» of this sign, and also to be in a state of transition from one degree of its manifestation to another [4, p. 78].

I. I. Turansky speaks of intensity from the point of view of stylistics and understands it as a semantic category based on the concept of quantity gradation in the broad sense of the word [11, p. 3].

All researchers dealing with this problem pay attention to the fact that the gradual quality can be either stepped in nature, such as the degree of comparison of an adjective, or represent a transition from one degree of intensity to the next without clear boundaries between them. Very often gradualism includes seme of comparativity [13, p.82].

The explicit or implicit comparison, which is the basis of gradualness, lies in comparing one object to another, which is supposed to have a sign in common with the first. And although the degrees of comparison of adjectives form the dominant category of gradual quality, this category is much broader, because it includes the designation of the absolute quantity of characters without the comparative seme.

Considering comparisons as phraseological units of a comparative type, scientists have found that intensity greatly influences the formation of their semantics (L. A. Lebedeva, E. I. Sheigal, T. V. Gridneva, Y. V. Bechka, E. V. Belskaya and others.). They tend to have an intensifying value, since they contain an intensity marker «very» at the level of the reference meaning. The marker «very» denotes the size of a sign which exceeds (or vice versa) a common sign and therefore becomes significant for a person in the verbal designation of the world [9, p. 301] (for example, very intelligent, very stupid). In the case of using other quantity markers (for example, "one», «two» - the exact value (quantity), «enough» - sufficient, «too much» excessive, «more» - comparative, «all» the maximum possible value (number)), there is always a more or less objective criterion for the truth of a judgment, some kind of external reference system, relative to which the value (quantity) of a sign is determined: an established system of measures, the presence of another comparative sign, objective physical properties of an object, etc. When using the semantic primitive «very», the reference point of the quality and quantity of a given quality is the norm - the

(C) O. S. Polishchuk

«International journal of philology» | «Міжнародний філологічний часопис» Vol. 10, № 1, 2019 
legalized, generally accepted order, state of things, pattern, rule. At the same time, the desired state of things is recognized [9, p. 303-308]. Estimated predicates are most often marked by an intensifying sense. Intensification of the feature allows selecting any object from the class of the same name. However, such a selection is not based on the objective measure of the manifestation of the sign, but on the nominal representation of the nominee about this signs one that differs significantly from the norm. Scientists speak of intensity as a «linguistic representation» as a semantic category, which is an integrating factor in an ordered set of multilevel language units [3, p. 31]. By qualifying the intensity category as semantic in a narrow and broad sense, the researchers turned to material from different languages, where this category applied to speech problems (S.E.Rodionova, A.V.Fedoruk), translation problems (I. I. Ubin, I. I. Sushchinsky), was considered as a component of the semantics of the word and idiom (E. I. Sheigal), studied on the basis of dialects (E.Belskaya), including its gradual characteristics (S.M.Kolesnikova, I. I. Turansky).

The purpose. The intention of this work is to study the gradual quality, which forms the basis of the functional-semantic field of comparativity. At the same time, we proceed from the unity of the semantic basis of the studied phenomenon in both languages and the differences in the ways of its expression.

Methods: comparative analysis, synchronous-comparative method, contextual method, analysis of implicit meanings.

Results. The problem of the status of the intensity category and its understanding remains one of the most discussed in modern linguistics, but still doesn't have a clear-cut solution. The presence of an extra-language referent gives this category an ontological status (as a category that lies within quantitative relations). At the same time, the intensity passes to the connotative level of language and speech and interacts with the categories of emotiveness, expressiveness and assessment. In the broad sense, intensity means a quantitative change of a sign: «the term intensity should be understood as all differences, which are reduced to categories of quantity, size, value, strength, etc. regardless of whether they are concrete ideas or abstract ideas» [2, $p$. 202]. In the center of this definition are quantitative differences. In addition, Balli notes that a quantitative difference, or a difference in intensity, is one of those generalizing categories into which we introduce the objects of our perception or our thought [2, p. 202-203]. L. Gerasimova also correlates the intensity and quantity, arguing that the intensity is an expression of amplification, that is, one of the types of quantitative characteristics of the trait [5, p. 17]. According to E. I. Sheigal, "the category of intensity, denoting an approximate quantitative assessment of quality, is a particular manifestation of the category of quantity, which is characterized as a non-discrete (indefinite) quantity» [12, p. 6]. I. I. Sushchinsky calls intensity as «potentiation» and defines it as «a semantic category reflecting a certain part of objectively existing quantitative gradations» [10, p. 3]. I. I. Turansky considers intensity as «the semantic category of a language, which is based on the concept of gradation of the quantity of the broad sense of the word» $[11, p .3]$. While researchers associate intensity with the measure of quantity and the quantitative characteristic of a trait, intensity is closely related to the category of measure. If the measure denotes the quantitative limits of the objective certainty of a given quality, then the intensity indicates the level of development of a sign within the framework of this measure,

(C) O. S. Polishchuk

«International journal of philology» | «Міжнародний філологічний часопис» Vol. 10, № 1, 2019 
which does not change this quality [12, $\mathrm{p}$. 13].

The problem of choosing an intensifier is interesting, because when nominee uses the phraseological unit, he aims to give an extremely clear and vivid characteristic to the described phenomenon. However, there may be cases of incorrect choice of the object of metaphorical transfer and, as a result, incorrect use of a phraseological unit or comparison. For example, if an Englishman wants to say that someone is wise, he will say "My grandpa is wise» (укр. Мій дідусь мудрий). In this statement there is no highlighting of the lexeme "wise». And in the statement of «My grandpa is wise as an owl» (укр. Мiŭ дідусь мудрий як сова), we can see an intensification of the sign of wisdom because of the comparison with the intensifier "owl». In Russian there is also intensifier "owl» but it bears diametrically opposite meaning. In the dictionary of comparisons we find: poc. «На взәляд что орел, а по уму как филин» - про наделку людину) [8].

\section{Conclusions}

and research prospects. As we can see, the choice of the intensifier is an extremely important aspect of the formation of the statement, so this problem requires further consideration. Heterogeneity and incalculability of lexical units, as well as the unlimited possibility of their combinatorics and a large historical the mobility of words opens the possibility of promising research in this area. This work is just a small part of semantic research on the adjectives of modern English and is an experience of describing adjectives of an intensifying nature.

\section{Список використаних джерел}

1. Nickel G. Contrastive Linguistics and Foreign language Teaching, Papers in Contrastive Linguistics. Cambridge, 1971. P. 5.
2. Балли Ш. Французская стилистика : пер. с фр. Москва : Изд-во иностр. лит., 1961. 394 с.

3. Бондарко А. В. Функциональная грамматика. Ленинград, 1984. С. 23.

4. Воротников Ю. Я. Структура функционально-грамматической сфреры градационности качественного признака.Филологические науки. 1987. № 4 C. 78 .

5. Герасимова Л. Я. Усилительные наречия В современном английском языке: автореф.дис.на соискание степени канд. филол. наук : 10.02.04. Ленинград, ЛГПИ им. А. И. Герцена. 1970. 26 c.

6. Гулыга Е. В., Е. И. Шендельс Грамматико-лексические поля В современном немецком языке. Москва: Просвещение, 1969. С. 114.

7. Козлова И. А. Градуальность качества в разных типах номинации на материале английских прилагательных: дис. ... канд. фрилол.наук: 10.02.04/ Москва, 1987. 180 с.

8. Мокиенко В. М., Никитина Т. Г. Большой словарь русских народных сравнений.Москва: ОЛМА Медиа Групп, 2008. $800 \mathrm{c}$.

9. Родионова С. Е. Интенсивность и ее место в ряду других семантических категорий. Москва: МАКС Пресс, 2004. $608 \mathrm{c}$.

10. Сущинский И. И. Система средств выражения высокой степени признака: автореф. дис.на соискание степени канд. фрилол.наук: 10.02.04. Харьков, 1977. 16 с.

11. Туранский И. И. Средства интенсифрикации высказывания В английском языке. Москва: Просвещение, 1969. С. 3.

12. Шейгал Е. И. Интенсивность как компонент семантики слова в современном английском языке: дис. ... канд. фрилол.наук: 10.02.04.Москва, 1981. 226 c.

13. Шинкарук В.Д. Проблеми семантичної структури речення В

\section{(C) O. S. Polishchuk}

«International journal of philology» | «Міжнародний філологічний часопис» Vol. 10, № 1, 2019 
сучасній теорії синтаксису // Південний архів. Філологічні науки. Херсонський державний університет. Херсон, 2004. Вип. XXV. С. 85-91.

14. Ярцева В. Н. Сопоставительная лингвистика и проблемы вариативности языка Филологические науки. 1986. № 1. C. 3.

\section{References}

1. Nickel, G. (1971). Contrastive Linguistics and Foreign language Teaching, Papers in Contrastive Linguistics. Cambridge, 15.

2. Balli, Sh (1961). Francuzskaja stilistika [French stylistics]. Moscow, 394.
3. Bondarko,
A
(1984).

Funkcionalnaja grammatika [Functional grammar]. Leningrad, 23.

4. Vorotnykov, Y. (1987). Struktura funkcionalno-grammaticheskoj sfery gradacionnosti kachestvennogo priznaka [Structure of functional and grammatical spheres of gradualism of qualitative sign], 78.

5. Herasymova, L. (1970). Usilitelnye narechija $v$ sovremennom anglijskom jazyke [Intensive adverbs in modern English]. Leningrad, 26.

6. Hulyha, E., Shendels, E. (1969). Grammatiko-leksicheskie polja v sovremennom nemeckom jazyke [Grammatical-lexical fields in modern German]. Prosveshchenye. Moscow, 114.

7. Kozlova, Y. (1987). Gradualnost kachestva $v$ raznyh tipah nominacii: na materiale anglijskih prilagatelnyh [Gradualism of quality in different types of nomination: based on English adjectives]. Moscow, 1980.

8. Mokyenko, V., Nykytyna, T. (2008). Bolshoj slovar russkih narodnyh sravnenij [Big dictionary of Russian folk proverbs]. Moscow, 800.

9. Rodyonova, S. (2004). Intensivnost i ee mesto $v$ rjadu drugih semanticheskih kategorij [Intensification among other semantic categories]. Moscow, 608.

10. Sushchynskyi, Y. (1977). Sistema sredstv vyrazhenija vysokoj stepeni priznaka [System of means for expressing the high degree of the sign]. Moscow, 16.

11. Turanskyi,Y.(1969). Sredstva intensifikacii vyskazyvanija $v$ anglijskom jazyke [Means of intensification in English]. Moscow, 173.

12. Sheihal, E.(1981). Intensivnost kak komponent semantiki slova $v$ sovremennom anglijskom jazyke [Intensity as a component of semantic in modern English]. Moscow, 226.

13. Shynkaruk, V.D. Problemy semantychnoi struktury rechennia $\mathrm{V}$ suchasnii teorii syntaksysu [Shynkaruk V.D. Problems of the Semantic Structure of the Sentence in the Modern Theory of Syntax] // Pivdennyi arkhiv. Filolohichni nauky [Southern Archive. Philological Sciences]. Khersonskyi derzhavnyi universytet. Kherson, 2004. Vyp. KhKhV. 85-91.

$$
\text { 14. Yartseva, V. (1986). }
$$

Sopostavitelnaja lingvistika i problemy variativnosti jazyka [Comparative linguistics and problems of variability of language]. Issue 1, 3.

(C) O. S. Polishchuk

«International journal of philology» | «Міжнародний філологічний часопис» Vol. 10, № 1, 2019 


\section{ДО ПРОБЛЕМИ ІНТЕНСИФІКАЦІЇ ТА ВИБОРУ ІНТЕНСИФІКАТОРА \\ О. С. Поліщук}

Анотація. Одним з основних питань, що відносяться до вивчення категорії інтенсивності і звертають на себе велику увагу лінгвістів, $є$ точний опис ії позиції серед інших семантичних категорій, визначення їх меж, взаємозв'язку $i$ взаємодії. Предметом даної роботи є семантична категорія інтенсивності, яка властива, принаймні, побічно, в принципі будь-якій мовній ситуації, і яка здатна утілюватися в мові найрізноманітнішими способами. 3 особливим інтересом вивчається рівень фрразеологізму, зокрема стійкі порівняльні звороти, оскільки (не лише) за допомогою їх зафріксувалися традиційні національні образи $i$ уявлення, що збереглися з найдревніших часів, і саме на прикладі стійких порівнянь можна виразно продемонструвати специфріку $і$ відповідності $в$ символіці окремих народів. Метою цієї роботи є, по-перше, аналіз суті і меж семантичної категорії інтенсивності, їі позицію і взаємовідносини з іншими близькими категоріями; по-друге, проведення структурованого огляду засобів вираження цієї категорії на відповідних мовних рівнях; i, по-третє, на тлі лінгвістичного корпусу зображувати зіставлення російських $i$ англійських стійких порівняльних зворотів.

Ключові слова. Інтенсифрікація, інтенсивність, інтенсифрікувальна гра дуальність, градація, ознака 